\title{
Rasionalisasi Kerapatan Stasiun Hujan Wilayah Sungai Rokan Berdasarkan Data Hujan Harian dan Variasi Tingkat Kesalahan
}

\author{
Rationalization of Rain Station Density in the Rokan River Basin Territory Based on Daily Rain \\ Data and Variation of Error Levels
}

\author{
Dehas Abdaa 1,*, Manyuk Fauzi², Ari Sandhyavitri ${ }^{3}$ \\ ${ }^{1}$ Jafung Pengairan Kementerian PUPR Jl. Cut Nyak Dhien No. 1, Pekanbaru, Indonesia \\ 2,3 Teknik Sipil, Universitas Riau, Kampus Bina Widya Jl. HR Soebrantas KM 12,5, Pekanbaru, Indonesia
}

* Penulis korespondensi : dehas.ab@gmail.com
Tel.: +62-85278672277
Diterima: 06 Mei 2021; Direvisi: 04 Juni 2021; Disetujui: 08 Juni 2021
DOI: 10.25299/saintis.2021.vol21(02).6839

\section{Abstrak}

Sebaran lokasi dan jumlah stasiun hujan ideal akan merepresentasikan kejadian hujan untuk menunjang akurasi informasi analisis di suatu wilayah. Kerapatan stasiun hujan eksisting dikaji berdasarkan metode standar World Meteorogical Organization sedangkan analisis rasionalisasi jumlah dan sebaran stasiun hujan berdasarkan data hujan harian dan variasi tingkat kesalahan menggunakan Metode Kagan-Rodda. Metode Kagan-Rodda telah digunakan di beberapa wilayah penelitian dengan beragam kategori fisiografi dan lingkup terbatas pada daerah aliran sungai. Sehingga dirasa perlu melakukan pengembangan cakupan penelitian untuk wilayah yang lebih luas yaitu Wilayah Sungai. Lokasi penelitian adalah Wilayah Sungai Rokan dengan fisiografi dataran tropis mediteran dan sedang seluas 22.455,28 $\mathrm{km}^{2}$. Stasiun hujan eksisting berjumlah 13 stasiun hujan dan 1 stasiun tidak lolos Uji F, koefisien luasan Thiessen eksisting tidak merata sebesar $165,03 \mathrm{~km}^{2}-3.758,12 \mathrm{~km}^{2}(0,007-0,17)$, dan korelasi hujan harian sebesar 0,03-0,37. Evaluasi analisis WMO menghasilkan 7 stasiun hujan yang memenuhi standar untuk luas daerah pengaruh sebesar 1.000-2.500 km2/stasiun. Perhitungan metode Kagan-Rodda dilakukan 2 skenario kesalahan perataan, skenario I dengan kesalahan perataan (Z1) sebesar 4,93\% menghasilkan 37 stasiun hujan, luasan pengaruh Thiessen 273,89 km²-1197,80 $\mathrm{km}^{2}(0,01-0,05)$, nilai $\mathrm{r}_{(0)}$ sebesar 0,20 , jarak antar stasiun hujan sejauh $26,36 \mathrm{~km}$, dan 2 stasiun memenuhi standar WMO. Sedangkan skenario II dengan $\mathrm{Z}_{1}$ sebesar $9,72 \%$ menghasilkan 10 stasiun hujan, dimana mempertahankan 2 stasiun, memindahkan 8 stasiun dan menutup 3 stasiun diperoleh luasan pengaruh Thiessen $1.691,71 \mathrm{~km}^{2}-2.488,21 \mathrm{~km}^{2}(0,08-0,11)$, jarak antar stasiun hujan sejauh $50,70 \mathrm{~km}$, dan seluruh stasiun memenuhi standar WMO. Rasionalisasi metode Kagan-Rodda skenario II relatif mewakili luas pengaruh wilayah dibandingkan skenario I.

Kata Kunci: Rasionalisasi Kerapatan, Stasiun Hujan, WMO, Kagan-Rodda

\begin{abstract}
The distribution of locations and the number of ideal rain stations will represent rain events to support the accuracy of analytical information in an area. The density of existing rain stations was assessed based on the standard method of the World Meteorological Organization, while the rationalization analysis of the number and distribution of rain stations based on daily rainfall data and variations in error rates used the Kagan-Rodda method. The Kagan-Rodda method has been used in several research areas with various physiographic categories and limited scope in watersheds. So it is necessary to develop the scope of research for a wider area, namely the River Basin. The research location is the Rokan River Basin with physiography of the Mediterranean and medium tropical plains covering an area of $22,455.28 \mathrm{~km}^{2}$. The existing rain stations are 13 rain stations and 1 station does not pass the $F$ test, the coefficient of the existing Thiessen area is uneven at $165.03 \mathrm{~km} 2-3,758.12 \mathrm{~km} 2$ (0.007-0.17), and the daily rainfall correlation is 0.03-0, 37. WMO analysis evaluation resulted in 7 rain stations that met the standard for the area of influence of 1,000-2,500 km2/station. The calculation of the Kagan-Rodda method is carried out in 2 scenarios of smoothing error, scenario I with an alignment error (Z1) of $4.93 \%$ resulting in 37 rain stations, the area of influence of Thiessen is $273.89 \mathrm{~km} 2-1197.80 \mathrm{~km} 2(0.01-0.05)$, the value of $\mathrm{r}(0)$ is 0.20 , the distance between rain stations is $26.36 \mathrm{~km}$, and 2 stations meet the WMO standard. While scenario II with Z1 of 9.72\% produces 10 rain stations, which maintains 2 stations, moves 8 stations and closes 3 stations, the Thiessen influence area is 1,691.71 km2-2,488.21 km2 (0.08-0.11), the distance between rain stations is $50.70 \mathrm{~km}$, and all stations meet WMO standards. The rationalization of the Kagan-Rodda method in scenario II is relatively representative of the area of influence compared to scenario $I$ :
\end{abstract}

Keywords: Rationalization of Density, Rain Station, WMO Method, Kagan-Rodda Method

\section{PENDAHULUAN}

Data stasiun hujan harus dapat menghasilkan data yang mewakili kejadian hujan terjadi yang memiliki distribusi hujan yang berbeda-beda. Sehingga dibutuhkan metode perhitungan yang tepat dan sumber daya manusia yang mumpuni.
Selain itu, keakuratan data curah hujan relatif bergantung pada kemampuan stasiun dalam

memantau kondisi karakteristik hidrologi. Kesalahan pengamatan, kerusakan peralatan pemantaunya, pengaruh faktor alam atau ketidak terwakilan besaran pemantau hujan pada suatu wilayah sungai dapat menyebabkan data yang 
dihasilkan tidak tepat [1]. Sehingga analisis hidrologi yang dihasikan untuk berbagai keperluan dalam pengeloaan sumber daya air menjadi tidak tepat. Oleh karena itu, sangat dibutuhkan ketersediaan data curah hujan yang akurat, tepat waktu, dan berkesinambungan untuk menunjang informasi analisis pengelolaan sumber daya air yang sesuai dengan kondisi suatu daerah aliran sungai (DAS) atau wilayah sungai (WS).

Stasiun hujan yang terpasang tidak sesuai dengan kondisi suatu wilayah, akan menyebabkan kekeliruan hasil analisis hidrologi karena tidak dapat mewakili kejadian hujan yang terjadi pada wilayah tersebut [2]. Penelitian [3] menjelaskan bahwa rasionalisasi stasiun hidrologi adalah analisis stasiun hujan untuk mengetahui jumlah stasiun data hujan yang ideal dan representatif terhadap kondisi suatu wilayah. Penentuan jumlah stasiun data hujan dan penempatannya relatif kompleks dan tidak dapat dilakukan secara sembarangan, akan tetapi membutuhkan evaluasi yang terus menerus [4].

Permasalahan ini relatif terkait dengan jaringan stasiun hujan dan penyebarannya harus dapat memperkirakan kondisi besar hujan yang sebenarnya terjadi dan ditetapkan secara optimal terkait biaya operasionalnya pada wilayah sungai. Setiap stasiun hujan memiliki luasan pengaruh (sphere of influence) yang digunakan untuk menunjukkan keterikatan atau korelasi dengan salah satu kejadian yang diamati stasiun lainnya dalam daerah tersebut.[4].

Badan meteorologi dunia, World Meteorological Organization (WMO), memberikan pedoman kerapatan jaringan stasiun hujan dibeberapa daerah. Semakin besar variasi hujan semakin banyak jumlah stasiun yang diperlukan [5]. Penetapan stasiun hujan tidak hanya pada penentuan jumlah stasiun yang dibutuhkan dalam suatu DAS, namun juga tempat dan pola penyebarannya.

Sedangkan menurut rodda (1970) petunjuk penyebaran stasiun hujan di dalam DAS, bersifat kualitatif dengan memanfaatkan koefisien korelasi hujan [4]. Kriteria penetapan stasiun hujan menurut Kagan tergantung pada jarak antar stasiun hujan yang diperoleh dari hubungan jarak stasiun terhadap korelasi hujan dari setiap stasiun curah hujan.

Analisis penentuan jumlah stasiun hujan yang dibutuhkan untuk mewakili kondisi suatu wilayah sungai menggunakan metode Kagan-Rodda dilakukan pada penelitian Rationalization of Rain Stations in the Ciliwung Cisadane River Basin, hasil pada penelitian ini menjelaskan bahwa perbandingan nilai kesalahan perataan 5\% dan 10\% dimana hasilnya menunjukan semakin rendah nilai kesalahan perataan yang digunakan mengakibatkan jumlah stasiun yang dibutuhkan semakin banyak dan jarak antar stasiun semakin rapat [2].
Penelitian ini dilakukan pada Wilayah Sungai Rokan yang merupakan Wilayah Sungai Lintas Provinsi. Wilayah Sungai Rokan terdapat banyak pengembangan infrastruktur sumber daya air, sehingga ideal dan representatif terhadap karakteristik hidrologi yang tepat dan akurat pada WS Rokan. Tujuan dari penelitian ini adalah melakukan kajian kondisi kerapatan jaringan stasiun hujan eksisting di Wilayah Sungai Rokan berdasarkan standar WMO serta melakukan analisis jumlah dan sebaran stasiun hujan yang ideal dan representatif berdasarkan Metode KaganRodda di Wilayah Sungai Rokan dengan mempertimbangkan penyebaran stasiun hujan menggunakan 2 skenario variasi tingkat kesalahan stasiun hujan.

\section{METODOLOGI}

\section{Lokasi Penelitian}

Penelitian ini dilakukan terhadap WS Rokan. Secara geografis WS Rokan berada $99^{0} 622$ BT $101^{0} 809$ BT serta 00068 LU - $2^{0} 307$ LU. Luas WS Rokan sebesar 22.455,28 $\mathrm{km}^{2}$ berhulu di rangkaian Bukit Barisan yang mengalir dari Provinsi Sumatera Utara, Provinsi Sumatera Barat, dan Provinsi Riau hingga bermuara ke Selat Malaka. Wilayah ini didominasi oleh penutupan lahan berupa kebun sawit, lahan pertanian, lahan terbuka, hutan, kebun karet dan sebagian kecil merupakan lahan terbangun, semak belukar, kebun campuran serta badan air [6].

\section{Pengumpulan Data}

Pada penelitian ini menggunakan data-data adalah sebagai berikut:

1. Data peta digunakan meliputi: peta administrasi dan peta Wilayah Sungai (WS).

2. Data inventarisir stasiun hujan yang digunakan adalah 13 stasiun hujan eksisting yang terdapat dalam Wilayah Sungai Rokan.

3. Data curah hujan yang digunakan adalah data curah hujan harian selama 15 tahun terakhir yang dimulai tahun 2005 sampai tahun 2019.

\section{Uji Kualitas Data Hirologi}

Uji kualitas data yang dilakukan dengan menggunakan uji stasioner. Uji stasioner dapat untuk menguji homogenitas suatu data dengan melihat kestabilan nilai varian dan rerata dari deret berkala [1] [7] [8] [9] [10]. Uji Homogenitas data curah hujan yang digunakan pada penelitian ini adalah uji $\mathrm{F}$ dan uji T. Uji $\mathrm{F}$ merupakan perbandingan pembagian jumlah data hujan menjadi 2 kelompok data dengan menghitung standar deviasi masing-masing kelompok data. Uji F digunakan untuk melakukan pengujian nilai varian dari deret data berkala. Pengujian ini menghitung pengaruh variabel bebas secara bersama-sama terhadap variabel terikat. Uji $\mathrm{F}$ pada penelitian ini menggunakan tingkat signifikansinya 0,05 (5\%). 
Uji T merupakan perbandingan rata-rata pembagian 2 kelompok data hujan dengan kestabilan 2 kelompok data. Uji T digunakan untuk menguji secara parsial masing-masing variable. Uji $\mathrm{T}$ digunakan untuk pengujian kesamaan jenis nilai rata-rata data. Adapun persamaan Uji F dan Uji T yang digunakan adalah:

$$
\begin{aligned}
& F=\frac{N_{1} \cdot S_{1}^{2}\left(N_{2}-1\right)}{N_{2} \cdot S_{2}^{2}\left(N_{1}-1\right)} \\
& t=\frac{\bar{X}_{1}-\bar{X}_{2}}{\sigma\left(\frac{1}{N_{1}}+\frac{1}{N_{2}}\right)^{1 / 2}}
\end{aligned}
$$

\section{Curah Hujan Rerata Wilayah}

Data pengukuran curah hujan dari satu stasiun hujan hanya mampu menghasilkan data yang merepresentasikan hujan pada satu areal hujan tertentu. Oleh karena itu, pada analisis data hujan secara umum diperkirakan dengan interpolasi atau mengambil rerata dari beberapa stasiun penakar hujan [11]. Perhitungan curah hujan rerata wilayah dilakukan dengan menggunakan poligon Thiessen.

Poligon Thiessen digunakan dalam menentukan luas pengaruh daerah stasiun hujan yang memiliki sebaran stasiun hujan dalam wilayah sungai yang tidak merata [12] [13]. Metode ini memperhitungkan bobot dari masing-masing stasiun yang mewakili luasan di sekitarnya. Curah hujan wilayah poligon Thiessen dihitung berdasarkan perbandingan masing-masing luas pengaruh stasiun hujan dikali dengan curah hujan pada stasiun hujan tersebut dan dibagi total wilayah. Adapun persamaan curah hujan wilayah poligon Thiessen ditampilkan pada persamaan (3).

$$
d=\frac{A_{1} d_{1}+A_{2} d_{2}+\ldots+A_{n} d_{n}}{A_{1}+A_{2}+\ldots+A_{n}}
$$

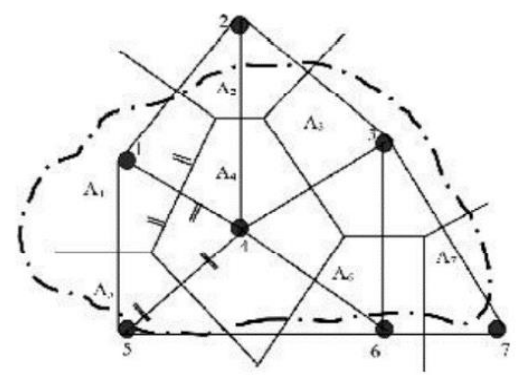

Gambar 1. Poligon Thiessen [11]

\section{Kerapatan Jaringan Stasiun Hujan Menggunakan Standar WMO}

Jaringan stasiun hujan mempunyai fungsi yang relatif penting, yaitu untuk mengurangi variabilitas besaran kejadian atau mengurangi ketidakpastian dan meningkatkan pemahaman terhadap besaran yang terukur maupun terinterpolasi [4]. Kerapatan jaringan (network density) dinyatakan dalam satu stasiun tiap luas tertentu. Dalam merencanakan jaringan, terdapat dua hal penting yang perlu dipertimbangkan, yaitu:

1. Jumlah stasiun yang diperlukan;

2. Penempatan lokasi stasiun-stasiun.

Jaringan stasiun hujan adalah luasan daerah pengaruh setiap stasiun hujan. Kerapatan jaringan didasarkan pada aspek teknis dan ekonomi dengan tingkat ketelitian yang dibutuhkan agar tercapai kerapatan jaringan yang optimum. Setiap jaringan stasiun hujan yang sudah ada perlu dikaji secara rutin setiap periode pengoperasian untuk meningkatkan kualitas datanya [14].

Organisasi meteorologi dunia (World Meteorological Organization, WMO) memberikan pedoman terkait kerapatan jaringan kerapaatan stasiun hujan di beberapa daerah. Standar WMO memberikan pedoman kerapatan minimum sebagai berikut [3] [15] [16]:

1. Daerah dataran tropis mediteran dan sedang dengan luas daerah $1.000-2.500 \mathrm{~km}^{2}$ untuk setiap stasiun curah hujan.

2. Daerah pegunungan tropis mediteran dan sedang dengan luas daerah $300-1.000 \mathrm{~km}^{2}$ untuk setiap stasiun curah hujan.

3. Daerah Kepulauan-kepulauan kecil bergunung dengan curah hujan bervariasi dengan luas daerah 140 - $300 \mathrm{~km}^{2}$ untuk setiap stasiun hujan.

4. Daerah arid dan kutub dengan curah hujan bervariasi dengan luas daerah $5.000-20.000$ $\mathrm{km}^{2}$ untuk setiap stasiun curah hujan.

\section{Kerapatan Jaringan Stasiun Hujan Menggunakan Metode Kagan-Rodda}

Penetapan jaringan stasiun hujan tidak hanya terbatas pada penetapan jumlah stasiun yang dibutuhkan dalam suatu DAS, melainkan tempat dan pola penyebarannya juga mempengaruhi [17]. Metode WMO belum dibahas tentang penyebaran stasiun hujan di dalam wilayah sungai yang ditinjau.

Penetapan jaringan stasiun hujan ada beberapa metode perhitungan yang dapat dilakukan, terdapat metode yang relatif sederhana dalam kebutuhan data yang digunakan maupun dalam langkah-langkah perhitungan. Metode tersebut adalah metode Kagan-Rodda. Keunggulan metode ini adalah jumlah stasiun hujan dapat ditetapkan dalam tingkat ketelilitian tertentu sehingga metode ini sekaligus memberikan pola penempatan dan penyebaran stasiun hujan yang representatif terhadap kondisi suatu wilayah [18].

Kagan melakukan penelitian pada tahun 1972 di daerah tropis yang hujannya bersifat lokal dengan luas areal penyebarannya yang tidak luas memiliki variasi ruang untuk hujan dengan periode ulang tertentu adalah sangat tidak bervariasi meskipun dalam kejadian sebenarnya menunjukkan suatu korelasi tingkat ketelilitian tertentu [4]. Perhitungan yang dilakukan pada metode ini menggunakan analisis statistik dengan menghubungkan kerapatan jaringan stasiun hujan 
dibandingkan kesalahan interpolasi dan kesalahan perataan antar stasiun hujan lainnya pada wilayah sungai tesebut.

Adapun langkah-langkah perhitungan yang dilakukan dalam analisis kerapatan jaringan metode Kagan-Rodda adalah sebagai berikut [4] [17] [19]:

1. Nilai koefisien variasi $(\mathrm{Cv})$ didapatkan dari data stasiun hujan yang diperlukan. Koefisien variasi (variation coefficient) adalah nilai standar deviasi dibandingkan dengan nilai rata-rata kumulatif hujan hitung dari suatu distribusi hujan.

2. Perhitungan jarak masing-masing stasiun hujan dengan data hujan disesuaikan dengan keperluan berdasarkan stasiun hujan yang sudah ada. Penentuan jarak tersebut tidak perlu memperhatikan orientasi arah, karena tidak akan memberikan dampak pada nilai korelasi antara kedua stasiun.

3. Hubungan yang telah dihasilkan tersebut, selanjutnya digambar pada grafik lengkung eksponensial. Berdasarkan grafik eksponensial tersebut diperoleh nilai radius korelasi $\left(\mathrm{d}_{0}\right)$ dengan menggunakan nilai rerata jarak antar stasiun (d) dan koefisien korelasi untuk jarak stasiun sejauh $\mathrm{d}\left(\mathrm{r}_{\mathrm{d}}\right)$.

4. Perhitungan nilai kesalahan perataan $\left(Z_{1}\right)$ dan kesalahan interpolasi $\left(\mathrm{Z}_{3}\right)$ dengan memperhatikan tingkat ketelitian ditetapkan. Ataupun sebaliknya, dapat dicari grafik hubungan antara jumlah stasiun dengan ketelitian yang diperoleh. Persyaratan nilai $\mathrm{Z}_{1}$ yang diizinkan $\leq 5 \%$.

5. Setelah jumlah stasiun hujan pada wilayah sungai yang ditinjau telah ditetapkan, maka dilakukan penentuan stasiun hujan hujan dengan jaring-jaring segitiga sama sisi dengan panjang sisi L (jaring Kagan-Rodda).

6. Penentuan jaring-jaring Kagan-Rodda tersebut, dapat melakukan rekayasa pergeseranpergeseran sedemikian rupa, sehingga jumlah simpul segitiga sama sisi yang berada di dalam wilayah sungai tersebut sama dengan jumlah stasiun hujan yang dihitung.

7. Simpul-simpul yang terbentuk pada jaring Kagan-Rodda merupakan penentuan lokasi stasiun hujan pada wilayah sungai tersebut.

Persamaan yang digunakan untuk melakukan analisis Kagan-Rodda adalah sebagai berikut [4]:

$$
\begin{aligned}
& r_{(d)}=r_{(0)} \cdot e^{\left(\frac{-d}{d(o)}\right)} \\
& Z_{1}=C_{v} \cdot \sqrt{\frac{\left[1-r_{(0)}+\left(\frac{0,23 \sqrt{A}}{d_{(0)} \sqrt{n}}\right)\right]}{n}} \\
& Z_{3}=C_{v} \cdot \sqrt{\frac{1}{3}\left(1-r_{(0)}+\frac{0,52 \cdot r_{(0)} \cdot \sqrt{\frac{A}{n}}}{d_{(0)}}\right)}
\end{aligned}
$$

$$
L=1,07 \sqrt{\frac{A}{n}}
$$

Penentuan nilai kesalahan yang diizinkan dilakukan dalam keadaan tertentu dan disesuaikan berdasarkan keperluan penelitian. Meskipun tidak dikaitkan dengan kriteria ekonomi yang optimal. Nilai kesalahan perataan $\left(\mathrm{Z}_{1}\right)$ adalah deviasi ratarata dalam kasus tertentu [20].

\section{HASIL DAN DISKUSI}

\section{Inventarisasi Stasiun Hujan}

Hasil inventarisasi stasiun hujan pada Wilayah Sungai Rokan diketahui jenis alat yang digunakan adalah jenis alat manual dan otomatis dengan sebaran di Kabupaten Bengkalis 1 stasiun (berada di Kecamatan Mandau), Kabupaten Rokan Hulu 8 stasiun (tersebar di Kecamatan Kunto Darussalam, Kecamatan Ujung Batu, Kecamatan Bangun Purba, Kecamatan Kepenuhan Hulu, Kecamatan Tambusai, Kecamatan Tambusai Utara, Kecamatan Rokan IV Koto, dan Kecamatan Rambah Samo), Kabupaten Rokan Hilir 3 stasiun (tersebar di Kecamatan Tanah Putih, Kecamatan Bangko Pusako, dan Kecamatan Bagan Sinembah), dan Kota Dumai 1 stasiun (berada di Kecamatan Bukit Kapur).

\section{Analisis Uji Kualitas Data Hidrologi}

Uji kualitas data hidrologi dilakukan untuk mengetahui stasiun hujan yang memiliki data yang baik. Hasil analisis uji $\mathrm{F}$ kualitas data hidrologi dengan $\alpha 5 \%$ diketahui 1 stasiun hujan tidak lolos Uji $F$ yaitu stasiun Lubuk Bendahara. Hasil uji $F$ menunjukan nilai $\mathrm{F}_{\mathrm{uji}}>$ nilai $\mathrm{F}_{\mathrm{c}}$ dengan nilai 35,39 > 4,21 . Data hujan pada stasiun Lubuk Bendahara memiliki sifat data hujan yang tidak homogen. Hal ini disebabkan tidak terdapat pengaruh yang signifikan secara bersama-sama antara variabel bebas terhadap variabel terikat. Sedangkan hasil analisis uji $\mathrm{T}$ menunjukan semua stasiun hujan termasuk stasiun Lubuk Bendahara lolos Uji T karena nilai $\mathrm{T}_{\mathrm{uji}}<$ nilai $\mathrm{T}_{0,975}$ menunjukan adanya pengaruh antara variabel bebas terhadap variabel terikat secara parsial.

\section{Analisis Curah Hujan Rerata Wilayah}

Analisis curah hujan rerata wilayah dilakukan dengan cara poligon Thiessen dengan luas pengaruh dari setiap stasiun curah hujan. Hasil perhitungan koefisien luasan poligon Thiessen Wilayah Sungai Rokan eksisting diketahui tidak merata sebesar 0,007-0,17, dimana 4 stasiun hujan memilki luas pengaruh lebih besar dari 10\% luas wilayah sungai $\left(>2.245,53 \mathrm{~km}^{2}\right)$, sedangkan 4 stasiun memiliki luas pengaruh lebih kecil dari 5\% luas wilayah sungai $\left(<1.122,77 \mathrm{~km}^{2}\right)$. Sedangkan 5 
stasiun hujan memilki luas pengaruh $5 \%-10 \%$ luas wilayah sungai $\left(1.122,77 \mathrm{~km}^{2}-2.245,53 \mathrm{~km}^{2}\right)$. Hal ini menunjukan lokasi stasiun hujan eksisting yang tersebar relatif tidak mewakili distribusi kejadian hujan di Wilayah Sungai Rokan. Sehingga pemilihan poligon Thiessen sesuai pertimbangan bahwa luas pengaruh daerah stasiun hujan yang memiliki sebaran stasiun hujan dalam wilayah sungai yang tidak merata dan sesuai pada penelitian [12] [13].

Perhitungan curah hujan rerata wilayah menggunakan data hujan harian maksimum masing-masing stasiun hujan dengan melakukan pengalian nilai faktor koreksi (Kr) Thiessen dan dihitung curah hujan rerata wilayah. Hasil perhitungan curah hujan rerata wilayah Thiessen Wilayah Sungsi Rokan disajikan pada Tabel 1.

Hasil perhitungan data curah hujan rerata wilayah tahun 2005 adalah 96,13 mm sedangkan tahun 2019 adalah 142,93 mm. Curah hujan rerata wilayah poligon Thiessen terendah pada tahun 2013 sebesar 60,16 mm dan curah hujan wilayah Thiessen tertinggi pada tahun 2011 sebesar 203,54 mm. Peningkatan hujan terjadi sejak tahun 2005 hingga 2011

Tabel 1. Curah Hujan Rerata Wilayah WS Rokan

\begin{tabular}{ccc}
\hline No. & Tahun & $\begin{array}{c}\text { CH Thiessen } \\
\text { (mm) }\end{array}$ \\
\hline 1 & 2005 & 96,13 \\
2 & 2006 & 116,19 \\
3 & 2007 & 109,31 \\
4 & 2008 & 121,43 \\
5 & 2009 & 160,45 \\
6 & 2010 & 140,13 \\
7 & 2011 & 203,54 \\
8 & 2012 & 111,03 \\
9 & 2013 & 60,16 \\
10 & 2014 & 88,88 \\
11 & 2015 & 75,83 \\
12 & 2016 & 70,75 \\
13 & 2017 & 95,14 \\
14 & 2018 & 119,94 \\
15 & 2019 & 142,93 \\
\hline
\end{tabular}

\section{Analisis Standar WMO}

Metode yang ditawarkan oleh Organisasi Meteorologi Dunia (World Meteorological Organization, WMO) dengan menghubungkan topografi wilayah dibandingkan dengan luas pengaruh dari setiap stasiun hujan pada wilayah. Evaluasi kerapatan stasiun hujan pada penelitian ini mengacu pada Standar WMO. Analisis WMO dihitung untuk mengetahui kondisi kerapatan penyebaran stasiun hujan eksisting yang akan menghindari defisiensi serius dalam pengembangan dan pengelolaan sumber daya air sesuai dengan tingkat pembangunan ekonomi dan kebutuhan lingkungan.

Mengacu pada standar WMO yang telah ditetapkan oleh WMO, diketahui bahwa Wilayah
Sungai Rokan merupakan daerah dataran tropis mediteran dan sedang dengan ketentuan luas daerah $1.000-2.500 \mathrm{~km} 2$ /stasiun. Perhitungan yang dilakukan pada Wilayah Sungai Rokan dengan luas 22.455,28 $\mathrm{km}^{2}$ adalah dengan melakukan perbandingan antara luas pengaruh setiap stasiun hujan dibandingkan dengan standar kerapatan minimum WMO. Hasil analisis luas pengaruh stasiun hujan eksisting dibandingkan dengan standar WMO disampaikan Tabel 2.

Berdasarkan hasil analisis pada Tabel 2, diketahui bahwa dari 13 stasiun hujan eksisting di Wilayah Sungai Rokan diperoleh 7 stasiun hujan yang memenuhi standar WMO. Adapun stasiun hujan tersebut adalah Pekan Tebih, Duri, Sedinginan, Bagan Batu, Bangun Jaya, Lubuk Bendahara, dan Dumai. Sedangkan stasiun yang tidak ideal seperti stasiun hujan Rambah Utama, Dalu-dalu, Pasar Tangun, Kota Lama dan Ujung Batu berada pada lokasi yang relatif dekat atau relatif rapat dengan stasiun hujan lainnya sehingga tidak memenuhi kerapatan minimal standar WMO. Hasil analisis ini merupakan pertimbangan perhitungan rasionalisasi stasiun hujan yang ideal dan representatif berdasarkan metode Kagan-Rodda berdasarkan variasi tingkat kesalahan.

Tabel 2. Analisis Standar WMO pada WS Rokan

\begin{tabular}{|c|c|c|c|c|}
\hline \multirow[t]{2}{*}{ No } & \multirow{2}{*}{$\begin{array}{c}\text { Stasiun } \\
\text { Hujan }\end{array}$} & \multicolumn{2}{|c|}{ Luas Pengaruh } & \multirow{2}{*}{$\begin{array}{c}\text { Kondisi } \\
\text { Standar } \\
\text { WMO }\end{array}$} \\
\hline & & $\left(\mathrm{Km}^{2}\right)$ & $(\%)$ & \\
\hline 1 & $\begin{array}{l}\text { Pekan } \\
\text { Tebih }\end{array}$ & $1.438,25$ & 6,40 & Ideal \\
\hline 2 & Duri & $1.573,22$ & 7,01 & Ideal \\
\hline 3 & Sedinginan & $1.642,34$ & 7,31 & Ideal \\
\hline 4 & Bagan Batu & $1.929,43$ & 8,59 & Ideal \\
\hline 5 & $\begin{array}{l}\text { Bangun } \\
\text { Jaya }\end{array}$ & $2.281,88$ & 10,16 & Ideal \\
\hline 6 & $\begin{array}{l}\text { Rambah } \\
\text { Utama }\end{array}$ & 562,68 & 2,51 & $\begin{array}{l}\text { Tidak } \\
\text { Ideal }\end{array}$ \\
\hline 7 & $\begin{array}{l}\text { Lubuk } \\
\text { Bendahara }\end{array}$ & $1.959,90$ & 8,73 & Ideal \\
\hline 8 & Dalu-Dalu & 854,29 & 3,80 & $\begin{array}{l}\text { Tidak } \\
\text { Ideal }\end{array}$ \\
\hline 9 & $\begin{array}{l}\text { Pasar } \\
\text { Tangun }\end{array}$ & $3.262,86$ & 14,53 & $\begin{array}{l}\text { Tidak } \\
\text { Ideal }\end{array}$ \\
\hline 10 & Ujung Batu & 165,03 & 0,73 & $\begin{array}{l}\text { Tidak } \\
\text { Ideal }\end{array}$ \\
\hline 11 & Kota Lama & 765,50 & 3,41 & $\begin{array}{l}\text { Tidak } \\
\text { Ideal }\end{array}$ \\
\hline 12 & Dumai & $2.261,77$ & 10,07 & Ideal \\
\hline 13 & $\begin{array}{l}\text { Bangko } \\
\text { Jaya }\end{array}$ & $3.758,12$ & 16,74 & $\begin{array}{l}\text { Tidak } \\
\text { Ideal }\end{array}$ \\
\hline
\end{tabular}

\section{Analisis Metode Kagan-Rodda}

Perhitungan yang dilakukan pada metode Kagan-Rodda ini dengan menghubungkan kerapatan jaringan stasiun curah hujan dibandingkan dengan nilai kesalahan interpolasi dan nilai kesalahan perataan antar stasiun curah hujan pada Wilayah Sungai Rokan. Nilai koefisien 
variasi $(\mathrm{Cv})$ data hujan didapatkan dari 13 data stasiun curah hujan sebesar 0,33. Hal ini menunjukan bahwa data hujan maksimal harian relatif seragam. Karena metode Kagan-Rodda ini merupakan metode statistik untuk mengetahui hubungan antara jarak antar stasiun, sehingga setelah mendapatkan nilai $\mathrm{Cv}$, dilakukan perhitungan nilai koefisien korelasi antar stasiun hujan.

Pada hasil perhitungan yang telah dilakukan pada WS Rokan ini diperoleh nilai koefisien korelasi (r) untuk hujan harian pada penelitian di WS Rokan ini relatif rendah yaitu 0,03 hingga 0,37 dengan rata-rata sebesar 0,13. Hasil perhitungan yang dilakukan untuk nilai koefisien korelasi (r) stasiun curah hujan harian memiliki korelasi data yang rendah dan relatif tidak kuat jika dibandingkan dengan jenis data bulanan atau tahunan. Hal ini dapat disebabkan karena distribusi hujan dan frekuensi kejadian hujan tidak merata dan seragam setiap hari pada setiap stasiun hujan pada Wilayah Sungai Rokan.

Nilai koefisien korelasi dihubungkan dengan jarak antar stasiun yang selanjutnya digambarkan dalam sebuah grafik lengkung eksponensial. Hasil penggambaran hubungan grafik lengkung eksponensial dilakukan untuk korelasi data hujan harian, ditampilkan pada Gambar 2 dibawah.

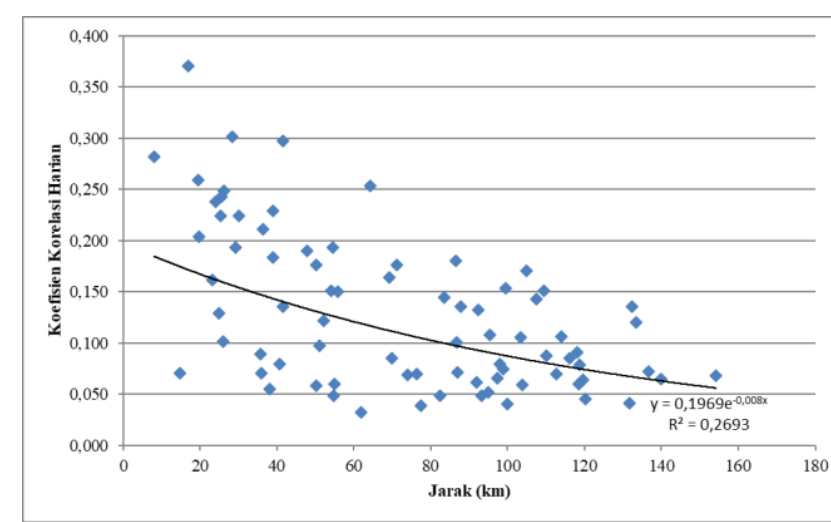

Gambar 2. Hubungan Koefisien Korelasi Hujan Harian dan Jarak Antar Stasiun Hujan

Pada data curah hujan harian, nilai korelasi stasiun curah hujan paling rendah 0,03 terdapat pada korelasi stasiun curah hujan Bangun Jaya dan stasiun curah hujan Lubuk Bendahara dengan nilai yang hampir mendekati nol. Hal ini disebabkan bahwa kedua stasiun curah hujan memiliki hubungan relatif lemah atau tidak ada hubungan sama sekali tetapi keduanya relatif bersifat searah. Penyebab hubungan antar stasiun hujan ini relatif lemah atau tidak terdapat hubungan sama sekali, karena jarak antar stasiun relatif jauh yaitu 61,80 $\mathrm{km}$, data yang tidak homogen, serta distribusi hujan dan frekuensi kejadian hujan tidak merata.

Sedangkan nilai korelasi hujan harian paling tinggi terdapat pada korelasi stasiun curah hujan Pekan Tebih dan stasiun curah hujan Rambah Utama dengan nilai 0,37 dengan nilai tidak sampai mendekati 1. Hal ini dapat disimpulkan bahwa kedua stasiun curah hujan memiliki hubungan relatif kuat atau terdapat hubungan dan keduanya relatif bersifat searah dibandingkan dengan stasiun hujan lainnya meskipun nilai korelasi tidak terlalu tinggi. Penyebab hubungan antar stasiun hujan ini relatif kuat, karena jarak antar stasiun tidak terlalu jauh yaitu 16,86 km dan data yang homogen.

Hal ini tidak berlaku pada stasiun curah hujan Lubuk Bendaharan dan stasiun curah hujan Ujung Batu yang memiliki jarak 8,07 km. Meskipun jarak antar stasiun relatif dekat tidak mengakibatkan hubungan nilai koefisien korelasi relatif kuat, hanya 0,57. Hal ini disebabkan karena sifat data hujan yang tidak homogen dan tidak terdapat pengaruh yang signifikan.

Sehingga disimpulkan bahwa kenaikan nilai salah satu relatif $(\mathrm{X})$ terjadi bersamaan dengan kenaikan nilai relatif yang lain (Y) dengan sifat data hujan yang homogen dan relatif bersifat searah. Nilai korelasi terbesar data stasiun hujan harian pada WS Rokan sebesar 0,37. Hal ini sesuai menurut [4], bahwa analisis jaringan stasiun curah hujan harian metode Kagan-Rodda memiliki nilai korelasi antar stasiun untuk data hujan harian dengan nilai relatif kecil.

Berdasarkan Gambar 2, diperoleh hubungan koefisien korelasi dan jarak antar stasiun hujan harian dengan nilai $r_{(0)}$ sebesar 0,20 dan nilai $d_{(0)}$ adalah 1/0,008 sehingga nilai radius koefisien korelasi untuk jarak yang relatif pendek $\mathrm{r}_{(\mathrm{d})}$ di WS Rokan tersebut adalah $125 \mathrm{~km}$. Batas kesalahan maksimal yang digunakan berdasarkan penelitian sebelumnya [2] [4] [8] [16] [17] [19] [21]. Nilai maksimal kesalahan $5 \%$ dan $10 \%$ untuk perhitungan kesalahan perataan stasiun hujan $\left(\mathrm{Z}_{1}\right)$ dalam menentukan jumlah stasiun curah hujan ideal pada WS Rokan ditampilkan pada Tabel 3.

Tabel 3. Hasil Perhitungan Nilai Kesalahan Perataan dan Kesalahan Interpolasi

\begin{tabular}{cccccccc}
\hline $\mathbf{n}$ & $\mathbf{Z}_{\mathbf{1}}$ & $\mathbf{\mathbf { Z } _ { 3 }}$ & $\mathbf{L}$ & $\mathbf{n}$ & $\mathbf{Z}_{\mathbf{1}}$ & $\mathbf{Z}_{\mathbf{3}}$ & $\mathbf{L}$ \\
& $\mathbf{( \% )}$ & $\mathbf{( \% )}$ & $\mathbf{( K m )}$ & & $\mathbf{( \% )}$ & $\mathbf{( \% )}$ & $\mathbf{( K m )}$ \\
\hline 1 & 33,84 & 20,36 & 160,34 & 20 & 6,77 & 17,70 & 35,85 \\
2 & 23,01 & 19,40 & 113,38 & 21 & 6,61 & 17,68 & 34,99 \\
3 & 18,45 & 18,96 & 92,57 & 22 & 6,45 & 17,66 & 34,18 \\
4 & 15,8 & 18,69 & 80,17 & 23 & 6,30 & 17,64 & 33,43 \\
5 & 14,02 & 18,50 & 71,71 & 24 & 6,17 & 17,63 & 32,73 \\
6 & 12,73 & 18,37 & 65,46 & 25 & 6,04 & 17,61 & 32,07 \\
7 & 11,73 & 18,26 & 60,60 & 26 & 5,92 & 17,60 & 31,45 \\
8 & 10,93 & 18,17 & 56,69 & 27 & 5,8 & 17,58 & 30,86 \\
9 & 10,27 & 18,10 & 53,45 & 28 & 5,69 & 17,57 & 30,30 \\
$\mathbf{1 0}$ & $\mathbf{9 , 7 2}$ & $\mathbf{1 8 , 0 4}$ & $\mathbf{5 0 , 7 0}$ & 29 & 5,59 & 17,56 & 29,77 \\
11 & 9,25 & 17,98 & 48,34 & 30 & 5,50 & 17,55 & 29,27 \\
12 & 8,84 & 17,94 & 46,29 & 31 & 5,4 & 17,54 & 28,80 \\
13 & 8,47 & 17,90 & 44,47 & 32 & 5,32 & 17,53 & 28,34 \\
14 & 8,15 & 17,86 & 42,85 & 33 & 5,23 & 17,52 & 27,91 \\
15 & 7,87 & 17,83 & 41,40 & 34 & 5,15 & 17,51 & 27,50 \\
16 & 7,61 & 17,8 & 40,09 & 35 & 5,08 & 17,50 & 27,10
\end{tabular}




\begin{tabular}{llllllll}
17 & 7,37 & 17,77 & 38,89 & 36 & 5,00 & 17,49 & 26,72 \\
18 & 7,15 & 17,74 & 37,79 & $\mathbf{3 7}$ & $\mathbf{4 , 9 3}$ & $\mathbf{1 7 , 4 8}$ & $\mathbf{2 6 , 3 6}$ \\
19 & 6,96 & 17,72 & 36,78 & & & & \\
\hline
\end{tabular}

Hubungan antara jumlah stasiun curah hujan dengan kesalahan perataan serta kesalahan interpolasi ditampilkan pada Gambar 3.

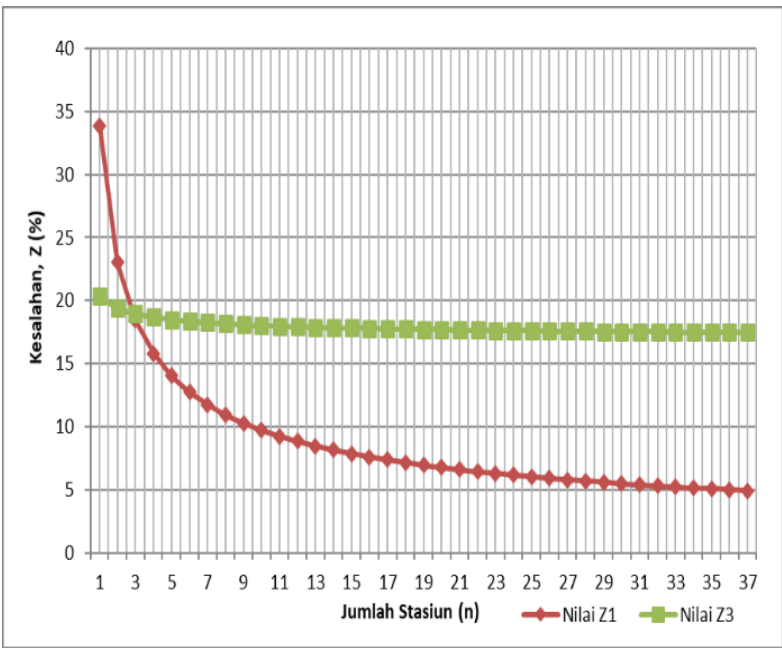

Gambar 3. Hubungan Jumlah Stasiun Data Hujan Harian Dibandingkan Nilai $\mathrm{Z}_{1}$ dan $\mathrm{Z}_{3}$

Semakin banyak jumlah stasiun curah hujan yang digunakan akan mengakibatkan kesalahan perataan dan kesalahan interpolasi akan semakin kecil serta memperbesar variasi distribusi hujan. Jumlah 13 stasiun hujan eksisting saat ini memiliki kesalahan $\mathrm{Z}_{1}$ sebesar 8,47\% $<10 \%$ dan $\mathrm{Z}_{3}$ sebesar $17,90 \%>10 \%$. Sehingga menurut [5], bahwa jumlah stasiun hujan yang dipasang pada aliran sungai yang terlalu banyak akan mengakibatkan besarnya biaya operasional dan pemeliharaan, sedangkan jika jumlah stasiun hujan terlalu sedikit akan menyebabkan hasil pencatatan hujan tidak dapat dipercaya.

Berdasarkan Tabel 3 dan Gambar 3, bahwa jumlah stasiun curah hujan yang akan dipilih dilakukan 2 (dua) skenario penempatan stasiun hujan berdasarkan kesalahan perataan maksimum $5 \%$ dan 10\%. Hasil perhitungan dengan nilai $\mathrm{Z}_{1}$ sebesar 4,93\% membutuhkan 37 stasiun curah hujan dan nilai $\mathrm{Z}_{1}$ sebesar 9,72\% membutuhkan 10 stasiun curah hujan.

\section{Rasionalisasi Sebaran Stasiun Curah Hujan dengan Metode Kagan-Rodda}

Perhitungan panjang sisi-sisi segitiga jaringjaring Kagan-Rodda yang dihitung dengan persamaan (7). Skenario I untuk $\mathrm{Z}_{1}$ sebesar 4,93\% yang direncanakan untuk 37 stasiun curah hujan dan panjang $L$ segitiga Kagan-Rodda yang didapat yaitu 26,36 km. Skenario I mempertahankan lokasi stasiun curah hujan Bagan Batu, Bangko Jaya, Duri, dan Kota Lama. Skenario I dengan pertimbangan data homogen, kondisi salah satu stasiun yang dipertahankan tidak ideal menurut standar WMO, variable lokasi stasiun yang berjauhan, dan nilai koefisien korelasi antar stasiun relatif baik stasiun yang dipertahankan.

Hasil skenario I pada Gambar 4 dirincikan sebagai berikut:

1. Mempertahankan lokasi 4 stasiun curah hujan Bagan Batu, Bangko Jaya, Duri, dan Kota Lama.

2. Memindahkan 9 stasiun curah hujan eksisting dilakukan pada stasiun Bangun Jaya sejauh 9,29 km kearah Utara, stasiun Dalu-Dalu sejauh 7,94 km kearah Selatan, stasiun Dumai sejauh 10,86 km kearah Utara, stasiun Lubuk Bendahara sejauh 20,08 km kearah Selatan, stasiun Pasar Tangun sejauh 6,06 km kearah Selatan, stasiun Pekan Tebih sejauh 12,00 km kearah Timur, stasiun Rambah Utama sejauh 7,44 km kearah Selatan, stasiun Sedinginan sejauh 10,63 km kearah Selatan, dan stasiun Ujung Batu sejauh 33,02 km kearah Selatan.

3. Menempatkan 24 stasiun baru.

Sedangkan skenario II untuk $\mathrm{Z}_{1}$ sebesar 9,72\% yang direncanakan untuk 10 stasiun curah hujan dan panjang $L$ segitiga Kagan-Rodda yang didapat yaitu 50,70 km. Skenario II mempertahankan lokasi stasiun curah hujan Bagan Batu dan Bangko Jaya. Skenario II dengan pertimbangan data homogen, memperbaiki salah satu variabel terikat yang berada pada kondisi ideal menurut standar WMO, lokasi stasiun tetap yang berdekatan, dan nilai koefisien korelasi antar stasiun relatif baik. Hasil skenario II pada Gambar 5 dirincikan sebagai berikut:

1. Mempertahankan lokasi 2 stasiun curah hujan Bagan Batu dan Bangko Jaya.

2. Memindahkan 8 stasiun curah hujan eksisting dilakukan pada stasiun Bangun Jaya sejauh 8,79 km kearah Utara, stasiun Dumai sejauh 10,13 km kearah Utara, stasiun Duri sejauh 6,16 km kearah Barat, stasiun Pasar Tangun sejauh 21,38 km kearah Barat, stasiun Rambah Utama sejauh 5,71 km kearah Timur, stasiun Pekan Tebih sejauh 32,39 km kearah Utara, stasiun Ujung Batu sejauh 46,63 km kearah Selatan, dan stasiun Sedinginan sejauh 56,32 km kearah Utara.

3. Menutup 3 stasiun eksisting dilakukan untuk stasiun Dalu-dalu, Lubuk Bendahara dan Kota Lama. 


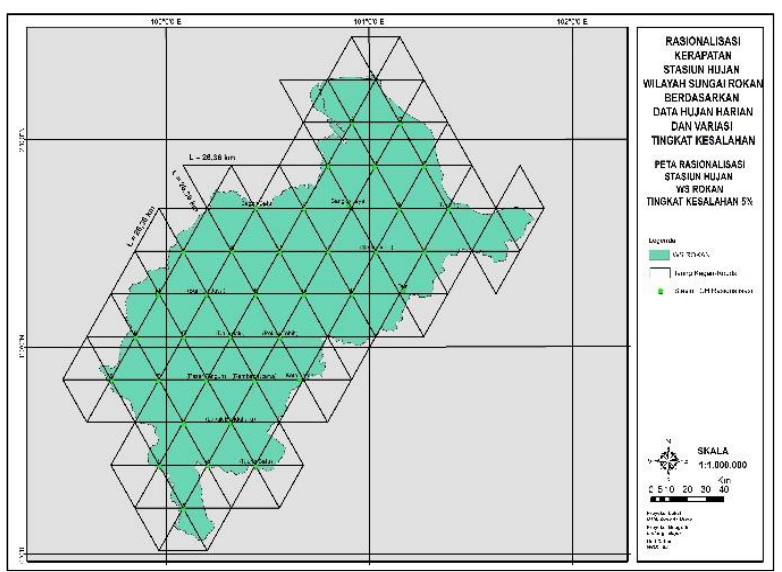

Gambar 4. Peta Rasionalisasi Stasiun Hujan Harian Skenario I Untuk Kesalahan 5\% pada WS Rokan

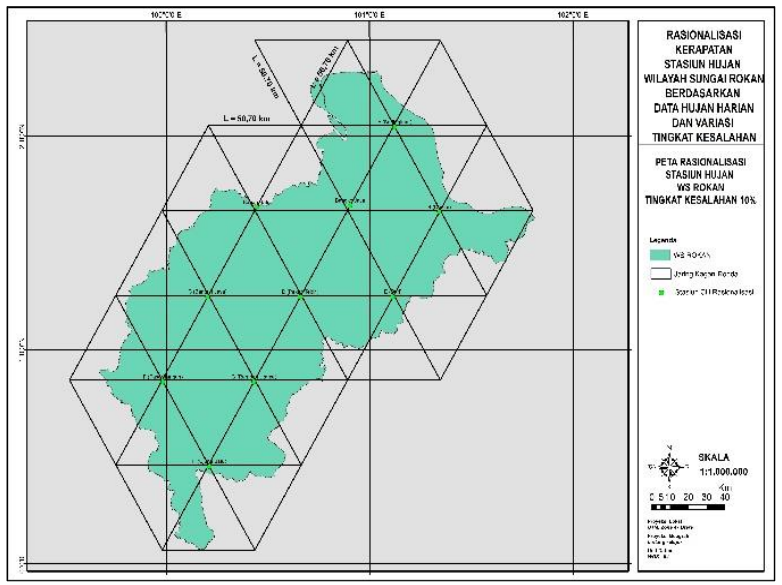

Gambar 5. Peta Rasionalisasi Stasiun Hujan Harian Skenario II Untuk Kesalahan 10\% pada WS Rokan

Hasil pemetaan analisis luas pengaruh wilayah dengan cara Poligon Thiessen rasionalisasi metode Kagan-Rodda skenario I dengan kesalahan 4,93\% menghasilkan luas pengaruh dan nilai faktor koreksi (Kr) dari 37 stasiun hujan memiliki luas pengaruh $273,89 \mathrm{~km}^{2}-1197,80 \mathrm{~km}^{2}(0,01-0,05)$, dimana 35 stasiun hujan memiliki luas pengaruh dibawah $1.000 \mathrm{~km}^{2}(<0,04)$ dengan rentang 273,89 $\mathrm{km}^{2}-968,21 \mathrm{~km}^{2}(0,01-0,04)$. Sedangkan 2 stasiun hujan memiliki luas pengaruh diatas $1.000 \mathrm{~km}^{2}$ $(>0,04)$ dengan rentang $1.033,53 \mathrm{~km}^{2}-1.197,80$ $\mathrm{km}^{2}(0,04-0,05)$. Hal ini menunjukan lokasi skenario I stasiun curah hujan relatif rapat di wilayah sungai yang dapat dilihat pada Gambar 6 .

Sedangkan hasil pemetaan analisis luas pengaruh wilayah skenario II dengan tingkat kesalahan 9,72\% menghasilkan luas pengaruh dan nilai faktor koreksi (Kr) dari 10 stasiun hujan sebesar 1.691,71 km² - 2.488,21 km² (0,08-0,11), dimana seluruh stasiun hujan memiliki luas pengaruh diatas $1.000 \mathrm{~km}^{2}$ dan dibawah $2.500 \mathrm{~km}^{2}$ $(0,04<X<0,11)$. Hal ini menunjukan lokasi kerapatan stasiun curah hujan skenario II relatif merata di wilayah sungai yang dapat dilihat pada Gambar 7.

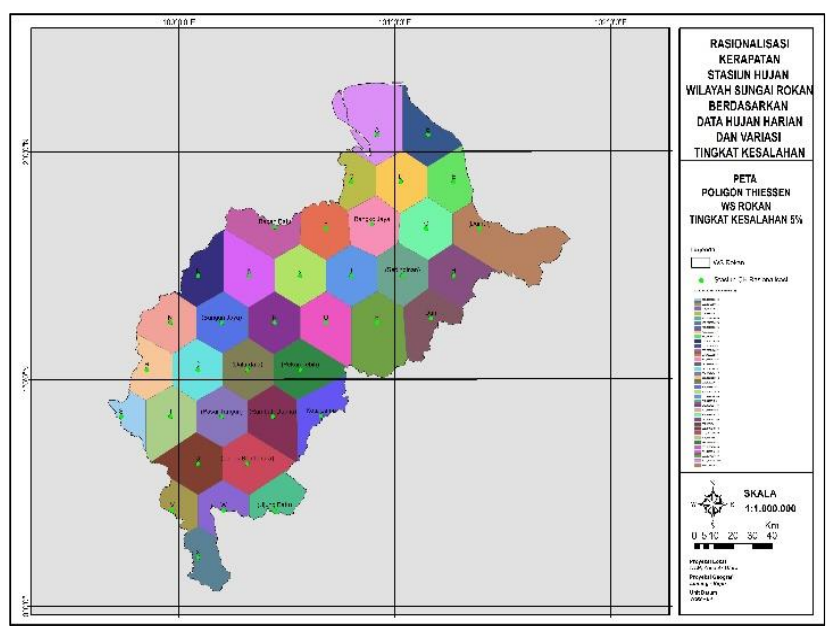

Gambar 6. Peta Poligon Thiessen Skenario I Untuk Hujan Harian Kesalahan 5\% pada WS Rokan

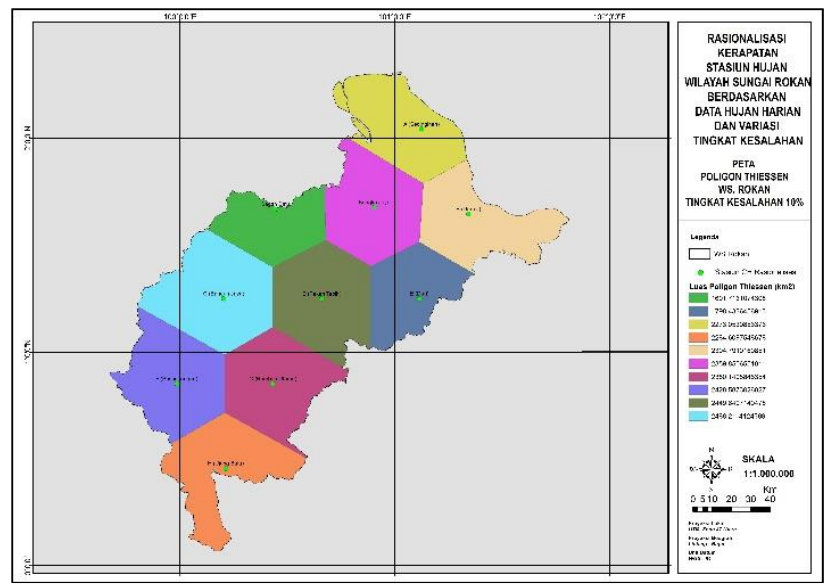

Gambar 7. Peta Poligon Thiessen Skenario II Untuk Hujan Harian Kesalahan 10\% pada WS Rokan

Meskipun jumlah stasiun hujan skenario I dengan kesalahan 4,93\% di WS Rokan menghasilkan jumlah 37 stasiun tetapi hanya 2 stasiun memenuhi standar WMO untuk kerapatan jaringan stasiun hujan $1.000-2.500 \mathrm{~km}^{2}$ yaitu stasiun Dumai yang dipindah dan stasiun A. Hal ini dilihat dari luas pengaruh wilayah stasiun Dumai yang dipindah sebesar 1.197,80 $\mathrm{km}^{2}$, stasiun A sebesar 1.033,53 km² dan 36 stasiun lainnya tidak memenuhi standar WMO untuk Wilayah Sungai Rokan.

Sedangkan jumlah stasiun hujan skenario II dengan kesalahan 9,72\% di Wilayah Sungai Rokan menghasilkan jumlah 10 stasiun dimana seluruh stasiun memenuhi standar WMO untuk kerapatan jaringan stasiun hujan $1.000-2.500 \mathrm{~km}^{2}$. Hasil perhitungan luas pengaruh wilayah terkecil $1.691,71 \mathrm{~km}^{2}$ dan terluas 2.488,21 $\mathrm{km}^{2}$ telah memenuhi standar WMO untuk kebutuhan jumlah dan penyebaran yang dapat mewakili kondisi WS Rokan. Hal ini disebabkan oleh data yang homogen, salah satu variabel terikat yang dipertahankan berada pada kondisi ideal menurut standar WMO, lokasi stasiun tetap yang berdekatan, dan nilai koefisien korelasi antar stasiun yang dipertahankan relatif baik. Skenario II menunjukan pola sebaran 
rasionalisasi stasiun curah hujan metode KaganRodda relatif lebih representatif dibandingkan skenario I.

\section{KESIMPULAN}

Hasil analisis standar WMO pada WS Rokan menghasilkan 7 stasiun curah hujan yang memenuhi standar WMO dari total 13 stasiun hujan eksisting. Hubungan koefisien korelasi dan jarak antar stasiun hujan harian $r_{(0)}$ sebesar 0,20 . Stasiun hujan yang ideal untuk WS Rokan dengan metode Kagan-Rodda dilakukan dengan variasi tingkat kesalahan 5\% dan 10\%. Hasil perhitungan skenario I dengan $\mathrm{Z}_{1}$ sebesar $4,93 \%$ membutuhkan 37 stasiun hujan dan panjang $L$ segitiga Kagan-Rodda yaitu 26,36 km. Stasiun yang dipertahankan 4 stasiun, dipindahkan 9 stasiun, dan menempatkan 24 stasiun baru. Sebaran skenario I menunjukan luas pengaruh wilayah relatif rapat tetapi hanya 2 stasiun memenuhi standar WMO untuk kerapatan jaringan stasiun hujan $1.000-2.500 \mathrm{~km}^{2}$. Sedangkan sebaran skenario II dengan $\mathrm{Z}_{1}$ sebesar 9,72\% membutuhkan 10 stasiun hujan dan panjang $L$ segitiga Kagan-Rodda yaitu 50,70 km. Stasiun yang dipertahankan 2 stasiun, dipindahkan 8 stasiun, dan menutup 3 stasiun menghasilkan luas pengaruh wilayah relatif merata, seluruh stasiun memenuhi standar WMO untuk kerapatan jaringan stasiun hujan $1.000-2.500 \mathrm{~km}^{2}$, dan distribusi hujan harian yang relatif kuat serta homogen karena lokasi antar stasiun yang dipertahankan berdekatan. Rasionalisasi metode Kagan-Rodda berdasarkan data hujan harian dengan skenario II relatif representatif dibandingkan skenario I pada Wilayah Sungai Rokan.

\section{REFERENSI}

[1] A. Bagiawan, S. M. Yuningsih, and D. Windatiningsih, "Pengujian Data Hidrologi Dalam Rangka Peningkatan Peningkatan Efektifitas dan Efisiensi Pengelolaan Sumber Daya Air," J. Sumber Daya Air, vol. 7, no. 193, pp. 1-17, 2011, doi: https://doi.org/10.32679/jsda.v7i1.379.

[2] F. Y. Pramono, Suripin, Suharyanto, and W. Sulistya, "Rationalization of rain stations in the ciliwung cisadane river basin," Int. J. Eng. Res. Technol., vol. 12, no. 12, pp. 2957-2963, 2019.

[3] F. A. R. Shiami and U. Lasminto, "Rationalization of Hydrology Station Network Using Rainfall Ground and Satellite Data," Int. Res. J. Adv. Eng. Sci., vol. 4, no. 3, pp. 225-229, 2019.

[4] S. Harto, Analisis Hidrologi. Jakarta: Gramedia Pustaka Utaama, 1993.

[5] B. Triatmodjo, Hidrologi Terapan, 6th ed. Yogyakarta: Beta Offset Yogyakarta, 2016.

[6] K. PU, Pola Pengelolaan Sumber Daya Air Wilayah Sungai Rokan. Jakarta, 2013.
[7] N. Pradipta, P. Sembiring, and P. Bangun, "Analisis Pengaruh Curah Hujan Di Kota Medan," Saintia Mat., vol. 1, no. 5, pp. 459468, 2013.

[8] L. S. C. Ranesa, L. M. Limantara, and D. Harisuseno, "Analisis Rasionalisasi Jaringan Pos Hujan Untuk Kalibrasi Hidrograf Pada Das Babak Kabupaten Lombok Tengah," J. Tek. PengairanPengairan, vol. 6, no. 7, p. 46, 2015.

[9] D. Susilokarti, S. S. Arif, S. Susanto, and L. Sutiarso, "Identifikasi Perubahan Iklim Berdasarkan Data Curah Hujan di Wilayah Selatan Jatiluhur Kabupaten Subang, Jawa Barat," J. Agritech, vol. 35, no. 01, p. 98, 2015,

doi: https://doi.org/10.22146/agritech.13038.

[10] D. B. Paraga, Nurhayati, and E. Yulianto, "Uji Konsistensi Data Hujan Dari Stasiun Hujan Yang Berpengaruh Diwilayah Kota Pontianak," JeLAST J. Elektron. Laut, Sipil, Tambang, vol. 7 , no. 3, pp. 1-6, 2020, doi: http://dx.doi.org/10.26418/jelast.v7i3.426 61.

[11] C. . Soemarto, Hidrologi Teknik, 2nd ed. Jakarta: PT. Gelora sar Pratama, 1999.

[12] H. Djafar, L. M. Limantara, and R. Asmaranto, "Studi Analisa Kebutuhan Jumlah Stasiun Hujan Berdasarkan Evaluasi Perbandingan Antara Analisa Hidrograf Banjir Dan Banjir Historis Pada Das Limboto Provinsi Gorontalo," J. Tek. Pengair., vol. 5, no. 2, pp. 172-181, 2014.

[13] A. C. Harifa, M. Charits, J. Setiono, and M. Khamim, "Evaluasi Jaringan Stasiun Hujan di Wilayah Sungai Dumoga Sangkub," Reka Buana J. Ilm. Tek. Sipil dan Tek. Kim., vol. 5, no. 1, p. 37, 2020, doi: 10.33366/rekabuana.v5i1.1607.

[14] E. Prawati and V. Dermawan, "Rasionalisasi Jaringan Stasiun Hujan Menggunakan Metode Kagan Rodda Dengan Memperhitungkan Faktor Topografi Pada Das Sarokah Kabupaten Sumenep (Pulau Madura, Jawa Timur)," Tapak, vol. 8, no. 1, pp. 79-90, 2018.

[15] WMO, Guide to Hydrological Practices Volume I Hydrology - From Measurement to Hydrological Information, 6th ed., vol. 53, no. 9. Geneva: WMO Publications Board, 2008.

[16] R. Junaidi, "Kajian Rasionalisasi Jaringan Stasiun Hujan Pada Ws Parigi-Poso Sulawesi Tengah Dengan Metode Kagan Rodda Dan Kriging," J. Ilmu-Ilmu Tek. - Sist., vol. 11, no. 1, pp. 22-31, 2015.

[17] Y. P. Islamiyanto, L. M. Limantara, and S. Wahyuni, "Analisa Dan Rasionalisasi Kerapatan Jaringan Stasiun Hujan Dengan Metode Kagan - Rodda Di Sub Das Lahor Malang Jawa Timur," J. Mhs. Jur. Tek. Pengair., vol. 3, no. 1, p. 35, 2019.

[18] K. PU, Pedoman Rasionalisasi Pos Hidrologi 
dengan Metode Stepwise, Analisa Bobot, Kriging, Kagan dan Analisa Regional. Jakarta, 2014.

[19] Z. R. Alfirman, L. M. Limantara, and S. Wahyuni, "Rasionalisasi Kerapatan Pos Hujan Menggunakan Metode Kagan-Rodda Di Sub Das Lesti," J. Tek. Sipil, vol. 8, no. 2, pp. 153-164, 2019.

[20] S. Arifah, E. Suhartanto, and D. Chandrasasi, "Rasionalisasi Jaringan Pos Stasiun Hujan Pada DAS Kemuning Kabupaten Sampang Menggunakan Metode Kagan-Rodda," J. Mhs. Jur. Tek. Pengair., vol. 1, no. 2, p. 15, 2018.

[21] Y. R. Siswanti, V. Dermawa, and E. Suhartanto, "Rasionalisasi Jaringan Pos Hujan Menggunakan Metode Kagan Rodda dengan Memperhitungkan Faktor Topografi pada Daerah Aliran Sungai (DAS) Sarokah Kabupaten Sumenep Pulau Madura," J. Mhs. Jur. Tek. Pengair., vol. 3, no. 2, p. 2, 2018.

\section{NOMENKLATUR}

A makna dari luas DAS (km)

Cv makna dari koefisien variasi

d makna dari jarak antar stasiun (km)

$\mathrm{d}_{(0)} \quad$ makna dari radius korelasi

F makna dari nilai hitung Uji F

L makna dari jarak antar stasiun (km)

n makna dari jumlah stasiun

$\mathrm{Nn}$ makna dari jumlah kelompok $\mathrm{n}$

$r_{(d)}$ makna dari koefisien korelasi untuk jarak stasiun sejauh d

$r_{(0)}$ makna dari koefisien korelasi untuk jarak yang sangat pendek

Sn makna dari standar deviasi kelompok n

$\mathrm{t}$ makna dari nilai hitung Uji t

$\bar{X}_{1} \quad$ makna dari nilai rata-rata data kelompok ke-

$$
\mathrm{n}
$$

$\mathrm{Z}_{1} \quad$ makna dari kesalahan perataan (\%)

$\mathrm{Z}_{3} \quad$ makna dari kesalahan Interpolasi (\%) 